\title{
A Case Study of Five Science Teachers' Understandings of Classroom Research and Their Willingness to Become Active Classroom Researchers
}

\author{
Rawatee Maharaj-Sharma \\ The University of the West Indies \\ St. Augustine, Trinidad and Tobago \\ E-mail: Rawatee.Maharaj-Sharma@sta.uwi.edu
}

Received: February 28, $2011 \quad$ Accepted: April 30, $2011 \quad$ doi:10.5539/ass.v7n9p158

\begin{abstract}
This article reports on the views of five secondary school science teachers who accepted the challenge to explore the self-assessment aspect of their practice with specific regard to their understandings of classroom research and their willingness to actively initiate and engage in classroom research. The approach is an explorative one and the accounts outline the context in which the teachers work, provide brief descriptions of their work, and consider what lessons from these case studies might guide or inform teachers and teacher educators in the personal and professional development of science teachers as researchers.
\end{abstract}

Keywords: Classroom research, Attitudes to research

\section{PREAMBLE}

In Trinidad and Tobago there is very little published work on teachers' views and feelings about their role as classroom researchers. It is against this background that the motivation for this work emerged. The author had spent four years training secondary school science teachers - at the School of Education at the University of the West Indies on the Postgraduate Diploma in Education - and had experienced a general sense of resistance by teachers to engage in non-mandatory classroom research initiatives. The Postgraduate Diploma in Education (PDEP) is a nine-month in-service teacher education/training programme.

In the current work, the teachers selected were all graduates of the Postgraduate Diploma in Education Programme with whom the author had worked closely during their stint of training at the University of the West Indies. In this regard therefore, the sample comprised only science teachers. It is important to note that this work is very preliminary and it is intended to serve as a springboard to begin the process of gauging and documenting teachers' attitudes to classroom research in Trinidad and Tobago.

\section{INTRODUCTION}

In Trinidad and Tobago, there is a general perception that teachers are the storehouses of knowledge and that their primary function is to meticulously impart knowledge to their students. Practising teachers have adopted varying unique styles of delivery which they have 'perfected' over time and many of them are ready, willing and able to convincingly defend their particular "teaching style" at the slightest hint of challenge. Until recently, however, there was no mandatory pre-service teacher-training programme to prepare secondary school teachers for entry into the classroom. The result therefore is that most of them entered the teaching service as untrained teachers, and so many of them muddled through their first few years of teaching until they eventually settled down to what they believed were 'comfortable method/s' that 'work for them'.

Once teachers get into such comfort zones, very few real attempts are made to critically assess or self-evaluate their practice in the physical settings in which they work. Despite the changing classroom clientele many teachers continue to practice within their comfort zone/s, which within recent times have not necessarily been meeting the needs of the dynamic clientele (Maharaj-Sharma, 2006). Teacher educators and trainers continue to make consistent efforts to encourage teachers who elect to pursue professional development through the PDEP, to actively enquire into their own practice, not only during training but after training as well. Despite these efforts, many teachers do not pursue classroom research beyond their formal training period. 
The purpose of this study was to examine five science teachers' understandings of classroom research and to informally assess their willingness to initiate research in their classrooms. Additionally, this work attempted to reveal some of the barriers that teachers perceive may hinder their efforts in this regard. Three research questions tailored the approach adopted in this project:

1. What are teachers' understandings of classroom research?

2. To what extent are teachers willing to engage in classroom research?

3. What are the perceived barriers experienced by teachers in their efforts to conduct classroom research?

\section{REVIEW OF CLASSROOM RESEARCH}

According to Cohen \& Manion (1998), any form of research has three fundamental characteristics that distinguish it from other types of inquiry approaches. Firstly, research is systematic and controlled and proceeds by adopting some basic approach that may have an inductive or a deductive methodology. Secondly, research is empirical, that is, the researcher must validate the findings by checking it against experience. In other words, subjectivity must be checked against objectivity. The third characteristic of research is that it is self-correcting, that is, not only does the scientific method have built-in mechanisms to protect scientists from humanly possible errors, but also procedures and results are open to public scrutiny by fellow professionals.

Classroom research, sometimes referred to as action research, is unique in that it not only has these characteristics but it provides an opportunity for the researcher [in this case teacher/s] to critically and formally inquire into his/her own practice in some systematic way in an attempt to promote and facilitate professional growth and development (Borg \& Gall, 1989). Many education experts agree that the role of 'Teacher as Researcher' is a fundamental pillar of professionalism and that the results of teachers' inquiries into their own practice can contribute significantly to their own unique situations as well as to the development of educational theory (Zee, 1998). Teachers can therefore use their own experiences in the classroom to investigate issues there, either independently or collaboratively, so as to provide deeper understandings of these issues and to uncover methodologies that can be used to effectively influence the teaching-learning relationship in their classrooms.

\section{CLASSROOM RESEARCH IN THE SCIENCE CLASS}

Very often science school students are 'mis-read' or 'mis-judged' by teachers as being incapable of coping with the rigors of scientific concepts, skills and theories because they do not respond positively to teachers' traditional styles of delivery. Teachers operate within their zones of comfort and often cast labels and/or blame on students without taking time to examine their own practice and the impact it makes [or does not make] on student learning. The result is that, often times, problems of poor motivation, negative attitude toward subject and low achievement arise in the classrooms (Dhal, 1995; Nakamura, 1999). In the local context, it is unclear what 'real efforts' are made by teachers to address these problems.

Brickhouse \& Boder (1992) and Glanz (2003) suggest that classroom research should become a significant aspect of teachers' practice as it is one of the surest ways to objectively assess the teaching/learning dynamism in the classroom and to evaluate the effectiveness of the teaching/learning strategies employed by teachers to achieve learning. Classroom research that is designed to identify and assess challenges that exist in schools and classrooms can reveal valuable insights into the underlying causes of these problems. Once these are known, suitable intervention strategies can be employed in attempts to address the problems. Researchers have suggested that it is through creative and innovative teacher interventions that many problems relating to low achievement and poor attitude are positively resolved (Reed, 2000). Furthermore, they agree that the responsibility to initiate activities and opportunities for identifying the causes of classroom problems and deciding on suitable intervention strategies to be adopted relies heavily on teachers' willingness, attitudes, abilities and their commitment to the profession (Reed, 2000; Shkedi, 1998). In addition, as suggested by Driel, Beijaard \& Verloop, 2001), teachers' existing knowledge, their beliefs and their attitudes are crucial considerations in any such undertaking.

The experience in the local context of Trinidad and Tobago has been that many teachers believe that they are not prepared, mostly in terms of their research abilities for such undertakings, but there are some teachers who believe that it is simply not their business to facilitate such undertakings and are generally unwilling to acknowledge the educational significance of this aspect of their profession. Other explanations offered by the literature for teachers' unwillingness to pursue classroom research include limitations of time, lack of resources and little or no support from school administration. 


\section{METHODOLOGY}

\section{The Sample}

In this study, 25 randomly selected science teachers from 25 secondary schools across Trinidad and Tobago were surveyed by way of a questionnaire consisting of $20 \%$ close-ended questions; to elicit biographical data; and $80 \%$ open-ended questions that focused on the research questions of the project. The teachers surveyed were all graduates of the PDEP and therefore had all been involved in some aspect of classroom research prior to this study. Based on their written responses, 5 teachers were purposively selected and interviewed to further explore their written responses and to provide the participants with ample opportunity to verbally expand on their understandings and their views in regard to their willingness to become classroom researchers. Background data and responses obtained from these five teachers were representative; in terms of content, context, views and ideas; of those of the larger group of 25 teachers and so detailed interviews were conducted with only these five teachers. The following accounts attempt to explore in specific ways what; for these five teachers; are their understandings of classroom research and to probe the extent of their willingness to engage in the process in a meaningful way. It also aims to uncover reasons why teachers may or may choose to become active classroom researchers and what challenges; perceived or otherwise; they face in this quest. In this regard therefore, it was important to interact intimately with each of the five participants to gain deep and meaningful insights into their views, ideas and feelings about this issue. [Pseudonyms were used for the five teachers who participated in the project]. The purposive selection process sought to co-opt the intense involvement of participants from different school types and different geographical localities across the country. It also sought to capture views/input from both male and female teachers.

\section{Data Collection and Data Analysis Procedures}

The open-ended section of the written questionnaire served to elicit from teachers their understandings of what classroom research is as well as to gauge the extent of their willingness to become classroom researchers. Opportunity was provided in the questionnaire for teachers to identify issues that might motivate them to engage in classroom research and also to elaborate on whether or not they thought of investigating the causes of the issues identified. Teachers were further asked to indicate what they thought were some of the challenges they face or might face if they decided to initiate and conduct classroom research in their respective contexts.

Guided by the research questions and the responses on the written questionnaire, a semi-structured interview protocol was prepared for the five science teachers selected. Before each interview, the responses presented on the respective written questionnaire were carefully studied; by re-reading several times; to obtain a thorough understanding of the views and opinions presented by each participant. Depending on the detail or ambiguity presented in the written responses, the semi-structured interview which followed was modified accordingly to maintain alignment with the stated research questions.

Each interview lasted about an hour and throughout the interview process questions were repeated for clarity and teachers' responses were probed to ensure that understandings, ideas and information were captured completely and in detail. The interviews were conducted 2 weeks after the questionnaires were administered.

Though detailed and significantly more searching, the interview questions followed closely, the questions on the questionnaire. Any ambiguities in the verbal responses were probed for clarity. Verbal responses that varied from information provided on the written questionnaire were explored by encouraging participants to explain, freely and fully; their views, feelings and opinions. Any verbal response which appeared to contradict data presented on the questionnaire was carefully probed and explored by allowing the participant to explain fully; prompting intervening questions [from the researcher] on a few occasions.

The interview tapes were subsequently transcribed and the transcripts reviewed several times - firstly each case was reviewed individually and then the cases were reviewed in conjunction with each other for comparative purposes. The transcriptions were coded and subsequently labeled in respect of the three research questions. All segments of the transcriptions that addressed the first research question were labeled 'Understanding of Research' (UOR). These segments were mostly in the first part of the transcriptions. Transcribed segments that addressed the second research question were labeled 'Willingness to Research' (WTR) and segments that addressed the third research question were labeled 'Barriers to Research' (BTR). Responses from some participants could not be assigned to any of these three labels and seem to convey a view that research was not part of teacher's job description. Responses that expressed this view were labeled 'Not My Job' (NMJ). 


\section{Case Study 1: Mark - Teaches upper secondary chemistry.}

Mark Smith is a chemistry teacher and has been in the teaching profession for ten years. He teaches mostly at the upper levels [forms four, five and six]. Mark teaches at one of the prestigious, denominational, schools located in the urban north part of Trinidad. Informal discussions with Mark while he was a student on the PDEP revealed that most of the students at his school come from wealthy families and many of them scored very high marks in the Secondary Entrance Examination (SEA). The SEA is a compulsory exam which all primary school students sit at the end of their primary schooling. It is used to place students in secondary schools. It focuses on Mathematics, English language and Creative Writing.

Literacy and numeracy challenges are almost non-existent at his school. Students generally move through the school in a somewhat routine way, attending classes, listening to lectures, taking notes and doing homework as instructed by the teachers in a mostly rote, and minimally interactive manner. Paid extra lessons whether from the teachers at the school or otherwise is an accepted practice as part of the education process for students of this school. Indiscipline is minimal at this school. Teaching, for Mark, has been a 'breeze'. The 'children are bright' they 'go for extra lessons ... they can read and write. ....and they don't bother teachers for extra help'. Administration is 'cool', Mark says, '... if I don't have a class, I don't have to be on the school compound...I can go in late and leave early...' Students 'never really complain about the way I teach...or the teaching strategies I use...'

\section{New learnings from Mark}

Written as well as verbal responses obtained from Mark revealed that his understanding of what classroom research involved was limited, that he was reluctant to engage in classroom research and he could identify several reasons why he was unwilling to become a classroom researcher.

\section{What are Mark's understandings of classroom research?}

Analysis of all segments of Mark's transcript that were labeled UOR in conjunction with his responses on the written questionnaire indicated that in his view, classroom research was a process that involved 'observing students... and writing down what they do in the classroom...' and 'how they behave'. He believes that 'listening to what they say about how they feel' is important and that by keeping a 'mental record' he knows 'how to deal with each of them'. His 'definition' after much probing was that 'classroom research involves finding out what happens in the classroom'. None of his responses suggested that Mark perceived classroom research to be a structured activity, involving some form of intervention, guided or informed by manifestations of students' behaviour, performance or attitude to the subject. He claims that 'thinking about' or 'engaging in classroom research' is not part of his 'responsibility' as a teacher and this was revealed from parts of his transcript that were labeled NMJ.

\section{To what extent is Mark willing to engage in classroom research?}

Simply put, Mark is unwilling to engage in classroom research. His response on the written questionnaire was short and blunt; ['I am not willing to engage in classroom research']. This view was further corroborated during the interview as Mark suggested, he 'has lots of other [personal] things to do with his time' and that 'teaching them chemistry is all he is paid to do'.

\section{Barriers to research for Mark}

During the interview it was evident that Mark enjoyed articulating all the possible challenges he envisaged he could face at his school and found every opportunity to cite these as reasons why he 'will not engage' in classroom research. Among the many envisaged barriers identified were, limited time to cover the scope of the syllabus, as well as 'no time to plan activities' and 'no financial compensation for research'. All three perceived 'barriers' emerged from the section of Mark's transcript coded BTR.

\section{Case Study 2: Sheri - Teaches lower secondary integrated science}

Sheri Norma has taught integrated science in a junior secondary school [located in rural Trinidad] for most of her nineteen-year teaching career. She has consistently been lobbying for improved conditions and facilities for her students - whiteboard, multimedia access and laboratory apparatus. At the junior secondary school indiscipline is a serious problem. Most students placed in this school performed poorly in the Secondary Entrance Examination [achieving between zero and thirty percent on the examination]; literacy and innumeracy challenges exist in almost every classroom. Sheri believes that she must capitalize on what students can do instead of focus on what they cannot do and so all her classes are interactive sessions where students learn not so much by reading and writing, but by working with their hands - building models, mixing solutions, talking about their 
observations and drawing charts to illustrate their learnings and acting out their feelings and ideas through drama and song. Many of the students at this school come from homes plagued by poverty, alcoholism and abuse. Sheri believes that it is her responsibility to give 'direction to the lives of these students'.

\section{New learnings from Sheri}

It was clear from both the written and verbal responses that Sheri was excited about initiating classroom research, and in fact the transcript revealed that since exiting the PDEP, Sheri had been constantly trying different approaches in her classroom to meet the needs of her students.

\section{What are Sheri's understandings of classroom research?}

Sheri indicated during the interview that she strongly believes that a 'teacher's job is far beyond teaching subject content' and that her job is to 'make better citizens out of my students'. She understands that her students come into her classroom with 'much baggage', which 'makes learning integrated science difficult for them' and that she has to 'find ways to get them to learn'. This she says is what she tries to do and in segments of her transcript coded UOR; Sheri articulates classroom research as 'a structured process ... that uses a suitable intervention strategy to address a teaching/learning issue in the classroom'. The issue/s she says can be identified after 'careful observations of students' behaviour and their engagement in classroom learning'. Furthermore, she suggests 'evaluating the effectiveness of any new strategy is an important part of classroom research'.

\section{To what extent is Sheri willing to engage in classroom research?}

All responses from both the written questionnaire and the interview revealed that Sheri is committed to finding 'new and interesting ways to get my students to participate in science learning' by employing a range of teaching/learning strategies. She insists that whenever she tries something new she documents her ideas and efforts before she begins, and documents her observations during the process. She says, 'I always evaluate the impact of the strategy at the end and [I] document its effectives or ineffectiveness'. This she says is 'very important'. Sheri believes that 'teacher as researcher ... is critical to the professional development of teachers'. Segments of her transcript coded WTR revealed that Sheri is very willing to actively engage in classroom research and has been engaged in such activity on many occasions, since exiting the PDEP.

\section{Barriers to Research for Sheri}

Sheri identifies many things that could deter her from 'doing what I do', but she believes that she has to be 'a change agent in the school' if she 'truly has to help the students'. She admits that 'time is never enough', but she has 'to make the best use of the time I have with my students'. At her school teaching aids and resources are 'very scarce' so 'I have to purchase a lot of the materials like markers and Bristol board...but I don't mind... sometimes I ask students to bring stuff from home like string, styrotex cups and rubber bands'. Sheri says 'the financial cost to me personally' is what she sees as the greatest 'barrier' to her engagement in classroom research, but she says that she always 'find a way to overcome this barrier'.

\section{Case Study 3: Pauline - Teaches lower secondary integrated science and upper secondary biology}

Pauline Peters teaches at a denominational school and has been a teacher for eight years. She herself has been through a tough life and faces her students while battling several of her own social challenges. She is sound in her content area and indicated that her motivation for pursuing the PDEP was to 'gain insights into new and exciting ways to deliver to my students'. The school is a new school, [established in 2001] and there are problems of inadequate staffing, lack of sufficient laboratory facilities and technical support. Students at this school are a 'mixed bunch', says Pauline, some of them 'are very bright' but some of them are 'remedial material'. There is no streaming at the school, so that any given class is truly a mixed ability class. This is the challenge for Pauline as she is unsure as to what she has to do to reach all her students. Pauline cites lack of enthusiasm and poor attitude toward science as the major challenges she face with her students. Because of these 'problems ...the students are also not performing as I would expect them to on their tests'. She claims that she tries to get her students to work in groups and to do projects on occasion, but that she is unable to manage the class whenever she deviates from teacher-led recitation delivery which is dominated mostly by textbook reading and some note-taking.

\section{New Learnings from Pauline}

The interpretation gathered from the responses given by Pauline indicated that she had a fair understanding of what is meant by classroom research and that she was in fact willing to conduct research in her classroom, but that she felt she was not sufficiently competent in research techniques. She also cited several barriers that discouraged her enthusiasm, in this regard. 


\section{What are Pauline's understandings of classroom research?}

Pauline was quick to attempt to define what she understood classroom research to be. She suggested that it is 'something you do to find out about the problems students have... and when you discover the problem/s you can think about doing something to solve the problem'. Despite several probing questions, Pauline never indicated that evaluation was part of the research process nor did she explicitly speak about documentation of the process. In other words, based on the interpretations of sections of her transcript coded UOR, there was no indication that Pauline understood classroom research to be a structured or planned activity.

\section{To what extent is Pauline willing to engage in classroom research?}

Pauline admits that she has never thought about doing any type of structured classroom research since exiting the PDEP. She admits further that she understands the importance of such research and the benefits it can add to the teaching/learning experience in the class as she recounts the research project she undertook while on the PDEP. She explains that she 'does not feel competent enough to do any research on her own.... I don't know where to start... what to look for ... and how to do it....if I knew how and if I had help.... I think I would do classroom research... because of these concerns, I am not willing to engage in classroom research ... I might end up doing more harm that good'.

\section{Barriers to Research for Pauline}

Based on the interview data as well as the responses from the questionnaire, it was obvious that Pauline's perceived barrier was a combination of limited confidence and competence in herself. She lacks confidence in research and competency in research skills and she sees these as the main barrier. This was clearly articulated in the written questionnaire. It would also seem from her responses during the interview that the lack of support from members of staff and others in the field of education to encourage and work collaboratively with Pauline is; in her view; a major barrier. Interestingly, Pauline never cited time as a barrier to classroom research. From segments of her interview labeled BTR, she believes that her 'lack of research skills is the main barrier'.

\section{Case Study 4: Deo - Teaches lower secondary agricultural science}

Deo Tobin is an agricultural science teacher who has been in the service for well over fifteen years. He, like Sheri, teaches at a junior secondary school but claims that the students 'don't want to learn...they are undisciplined ... and do not like to read or write'. He implies that there is very little he can do 'to help them learn anything'. Deo still uses chalk and blackboard to teach; he believes that 'this is what worked for him [as a student] and this is what has to work for them [his students]'. He is actively involved in the teachers' union and aggressively lobbies for better salaries and benefits for teachers, because he believes that 'dealing with these children is becoming more and more difficult'. Deo admits that he arrives at class late because he 'gives the children time to settle down'. There are no charts in his classroom and all he takes with him to the class is the course textbook. Clinical supervision of his classes while on the PDEP revealed that his classes are generally noisy and Deo has great difficulty maintaining classroom control and student attention. He is known to shout in threatening tones on occasion.

\section{New Learnings from Deo}

Deo had no grounded explanation when asked to articulate his understandings of classroom research, and nothing in his written or verbal responses suggested that he was open to the idea of becoming a classroom researcher. His transcript was riddled by complaints and criticizisms about the school, the students and the system in general.

\section{What are Deo's understandings of classroom research?}

Deo's concept of classroom research did not focus on the students. His view of classroom research was one that entailed 'providing students with materials and books to do research in the classroom'. It was clear from all his verbal responses coded UOR that Deo understood/interpreted classroom research to be an activity in which 'students are engaged' in a 'process of interacting with stimulus material and academic literature' to 'find out information about a topic'.

[In this case, the researcher intervened - but only after fully exploring his understandings as expressed verbally - to explain the idea of classroom research to Deo. The notion articulated was a structured approach that involved employing appropriate intervention strategies to understand/gauge/treat perceived problems related to the quality of the teaching/learning process that occurs in the classroom. It was also explained to Deo that evaluation of the intervention/s used (during and at the end of the treatment) was an important part of classroom research.] 


\section{To what extent is Deo willing to engage on classroom research?}

Once the researcher was satisfied that Deo had made the mental transition in his understanding of what was meant by classroom research, he was asked about his willingness to engage in the process. His responses were generally vague and curt, despite repeated but gentle probing. Segments of his transcript labeled WTR revealed that Deo was not willing to do anything more than 'teach them agricultural science' because 'I'm not paid to do anything else'. He indicates further, 'I don't think I can do anything to help these children learn if they don't want to learn.... most of them are not interested in any help'. Deo clearly shared sentiments that were in some ways similar to those expressed by Mark in regard to his willingness to engage in classroom research.

\section{Barriers to Research for Deo}

Given that initially Deo did not have a working understanding of the features of classroom research and about what was involved in the process, it was not clear from his responses whether the 'barriers' he spoke of were in reference to classroom research specifically, or if they were perceived 'barriers' of a more general nature which he encountered in his own practice. Careful and repeated analysis of his actual comments on audio-tape as well as his transcript suggested that the latter was more likely the case; in other words, the perceived 'barriers' Deo identified were elements/issues 'he felt' could impede his attempts at engaging in classroom research [of the nature explained to him by the researcher]. These were all in reference to him 'not being able to teach them all they need to learn ... because they are undisciplined ... have social problems ... and cannot concentrate in classes'. None of his comments/responses in relation to the perceived barriers conveyed the idea that time, limited resources or administrative support or even his own lack of understanding of the nature and potential of the process of classroom research were barriers that could pose challenges to him and other teachers who might want to engage in classroom research.

\section{Case Study 5: Andrew - Teaches physics at all levels}

Andrew De Pezia is a physics teacher and while he is over forty, he has only been in the teaching profession for four years, having worked in industry before entering the teaching profession. Andrew teaches at a prestigious denominational school where the students are described as 'the cream of the crop'. Most of them come from wealthy families and are generally self-motivated to learn. Andrew indicated that his decision to pursue the PDEP was to move up the ranks into administration. His classes are totally teacher-controlled with total teacher telling. The few instances he attempted to use multimedia to teach a lesson really reduced the session to a glorified lecture, as revealed from clinical supervision prior to this project. He has also made several conceptual flaws while teaching physics to students on a number of occasions. He believes that his students want to land themselves big jobs and are willing to work towards that end, and his job is 'simply to tell them what they need to learn and to work through past paper examination questions with them'. Andrew admits that sometimes his students come to class knowing more than he does about the topic because they take a lot of extra lessons and most times have already covered the topic.

\section{New Learnings from Andrew}

Andrew articulated what his perception of classroom research was and indicated that given his own view and the context in which he teaches he has never given much thought to conducting research in his classroom, but he admits that it might be a good thing to do to gain insights into students' performance and attitudes.

\section{What are Andrew's understandings of classroom research?}

After much thought, Andrew responded to this question by giving a very brief statement. He said, 'from what I know and recall from the Dip. Ed. Programme, classroom research is about doing things differently in your classroom to find a solution to a problem you are having in your classroom'. When probed a bit further, Andrew explained that it involved 'choosing a suitable intervention strategy to address the problem ... use the strategy to teach a unit of lesson to the students and them evaluate how well the strategy worked to solve the problem you started of with'. Further probing resulted in the follow response, 'that's all I understand and remember from the curriculum study'. [The curriculum study is an action research report which all teachers who pursue the PDEP, are expected to produce as part of the requirement for the programme.]

\section{To what extent is Andrew willing to engage in classroom research?}

From segments of his transcript coded WTR, Andrew admits that after graduating from the PDEP, he never gave 'much thought' to any form of classroom research. Additionally, he indicates that he does not see classroom research as 'part of my job description' nor does he see the benefits of any such activities to his students because, as he explains, 'my students are bright, most of them are highly motivated and many of them take extra [private] lessons ... often times they know their work even before coming to class'. Andrew questions, 'what will be the 
use of classroom research in this case'? He suggests 'I'll just be wasting my time'. It would seem that while Andrew appreciates the potential of classroom research, he is unwilling to engage in the process within his context.

\section{Barriers to Research for Andrew}

From segments of the interview data coded BTR, Andrew identifies several barriers that could deter him from conducting research in his classroom, if he decided to do so. Among these was 'already insufficient time to complete the syllabus, so where will the time to do research be found'? He also spoke of the lack of administrative and technical support and the fact that there is no financial compensation for such activities. He did indicate however, at the end of his interview, that in his view all these barriers can be overcome by someone who is willing to conduct classroom research, but he further indicated that he is not willing to challenge any of these, because his students 'do not need any intervention to learn'.

\section{Summary of Case Studies}

These cases reveal how five science teachers from different backgrounds with different profiles view the concept of classroom research inclusive of their willingness to pursue classroom research and the barriers or perceived barriers they face or may face in such an undertaking. The five teachers involved in this project volunteered to participate without reservations, each indicating that the findings will provide, for them, insights and new learnings about the way they see themselves in their profession. It was obvious from the openness and comfort with which they expressed their thoughts, views and feelings that the teachers were articulating truthfully and unreservedly. The researcher is indeed extremely grateful to them all for their openness.

The findings revealed that each teacher is different from the four others and this realization gave birth to speculation in the researcher's mind; the speculation that perhaps each of these teachers represents a different category of teacher in our education system. Indeed, a more detailed study with a much larger group of teachers will be needed to support such a speculation, but if we assume that this is even remotely tempting then the findings of this study would be significant, in a general sense, in the context of classroom practice and teacher professionalism. Additionally, for the five teachers involved in this project, the overall findings in each case seem to correlate in some crude way with their professional profile. The researcher ventured further to attach a label to each teacher. These labels were arrived at from subjective interpretations of the following:

- Written questionnaire responses

- Oral interview responses

- Informal interactions and observations (during the current work)

- Historical record and recall of teachers (during the PDEP)

Table 1 summarizes these subjective categories for the five teachers in this project; the labels as gleaned from the researcher's perspective.

\section{Insert Table 1 about here DISCUSSION/CONCLUSION}

The intention at the start of the project was not to use the data obtained from these five teachers to categorize teachers in general but simply it was to explore in some detail what were their views having seemingly different professional outlooks in respect to their understandings of and involvement in classroom research. During the data analysis phase of the project the categorization seemed to easily emerge from interpretations [by the researcher] of both the written and verbal responses given by the teachers.

The content-centred teacher, like Mark Smith, views content coverage and content dispensation to students as the most important aspect of the teaching profession. Teachers like Sheri Norma, place the students at the centre of the teaching/learning process and employ a variety of strategies to meet the needs of the students. Pauline Peters believes that meaningful learning for her students is most important and she believes further that teachers must be knowledgeable when attempting different strategies in the classroom to ensure that these strategies do not affect students' learning in any negative way. The self-centred teacher, like Deo Tobin, is of the view that students' learning is their responsibility and that the teacher's role is not necessarily to make a difference in the lives of students but simply to help only those students who are willing to help themselves. Andrew, the school-centred teacher sees his function within the school context and not within the classroom context and believes that student-teacher classroom engagement in the learning process is peripheral to the school as far as his commitments go.

The findings of this study clearly suggest that there are teachers in the system that do not see themselves as reflective practitioners but merely as knowledge bearers whose role is to dispense knowledge. [Reflective 
practitioners are actively engaged in constant review and reassessment of their practice and the impact it has on students (Schon, 1987)]. Three of the five teachers surveyed in this project did not view themselves as change agents either in the education process or in the education system. It is noteworthy that these three teachers were male teachers and that the two female teachers surveyed both indicated that, while their role included knowledge dispensing, they also felt that it was part of their professional responsibility to make meaningful differences in the lives of their students. It will be interesting to see what a more detailed comparative study of the relationship between teachers' gender and the way they view themselves as practitioners/educators would reveal.

The findings of this project also have implications for teacher training and professional development programmes like the PDEP suggesting that there is a need to emphasize in more stringent terms the importance of inculcating the research attitude among teachers who pursue professional training. As suggested by Cohen \& Manion (1998), this is one aspect of teachers' professional development that is often ignored and in this regard, there is a pressing need for teachers to be exposed further to methodologies and procedures on how to initiate and develop their own action research projects - in meaningful ways - based on problems that exist in their classrooms. Meaningful partnerships between teacher educators and other similar stakeholders seem to be a critical requirement in the structuring of post-training initiatives and activities to evaluate/assess teachers' progress and development in the area of classroom research. There is an obvious need to foster collaborative efforts between school administrators and teacher educators to encourage, monitor, guide and assist teachers when they undertake action research projects in their classrooms.

There is no doubt that challenges will emerge for teachers who are willing to make this transition in their practice (Brickhouse \& Boder, 1992). Significant efforts primarily in terms of funding, support, infrastructure and revised workloads, perhaps even increased staffing at schools, will have to be made, to make this transition palatable to teachers. Policy makers, the education ministry and other support institutions may even have to comprehensively review the appointment criteria and performance appraisal of teachers if this thrust is to be embraced and pursued in meaningful ways that will benefit our students. Furthermore, as suggested by Zee (1998), a move towards developing teachers who are researchers could have significant positive implications for teacher professionalism and teacher professional development in Trinidad and Tobago.

\section{References}

Borg W. R. and Gall, M. D. (1989). Educational research: an introduction. New York, Longman.

Brickhouse, N. M \& Boder, G. M. (1992). The beginning science teacher: Classroom narratives of convictions and constraints. Journal of Research in Science Teaching, 29, 471-485. doi:10.1002/tea.3660290504, http://dx.doi.org/10.1002/tea.3660290504

Cohen, L. and Manion, L. (1998). Research methods in education. London, Routledge.

Creswell, J. (2002). Educational research: Planning, conducting and evaluating quantitative research. Upper Saddle River, NJ, Merrill Prentice Hall.

Dahl, K. L. (1995). Challenges in understanding the learner's perspective. Theory into Practice, 34, 124-130. doi:10.1080/00405849509543669, http://dx.doi.org/10.1080/00405849509543669

Denzin, N.K. \& Lincoln, Y.S. (1998). Collecting and interpreting qualitative materials. Thousand Oaks, CA, Sage.

Glanz, J. (2003). Action research: An educational leader's guide to school improvement. Christopher-Gordin.

Johnson, M. (2002). Teacher as researcher. The Science Teacher, 69(3), 40-42.

Maharaj-Sharma, R. (2006). Students of Today. Trinidad Express, November $28^{\text {th }}, 2006$.

Nakamura, R. M. (1999). Healthy classroom management. Australia, Wadsworth Thompson Learning.

Reed, C. (2000). Teaching with power: Shared decision-making and classroom practice. New York, Teachers College Press.

Schon, D. (1987). Educating the reflective practitioner. San Francisco, CA, Jossey-Bass.

Shkedi, A. (1998). Teachers' attitudes towards research: A challenge for qualitative researchers. International Journal of Qualitative Studies, 11(4), 559-577. doi:10.1080/095183998236467, http://dx.doi.org/10.1080/095183998236467

Van Driel, J.H., Beijaard, D. \& Verloop, N. (2001). Professional development and reform in science education: The role of teachers' practical knowledge. Journal of Research in Science Teaching, 38(2), 137-158. 
doi:10.1002/1098-2736(200102)38:2<137::AID-TEA1001>3.0.CO;2-U, http://dx.doi.org/10.1002/1098-2736(200102)38:2<137::AID-TEA1001>3.0.CO;2-U

Zee, E. H. van. (1998). Fostering elementary teachers' research on their science teaching practices. Journal of Teacher Education, 49(4), 245-265. doi:10.1177/0022487198049004002, http://dx.doi.org/10.1177/0022487198049004002

Table 1. Teachers' Position on Classroom Research

\begin{tabular}{|c|c|c|c|c|}
\hline Teacher & $\begin{array}{l}\text { Understanding of } \\
\text { research }\end{array}$ & $\begin{array}{l}\text { Willingness to } \\
\text { research }\end{array}$ & $\begin{array}{l}\text { Barriers to } \\
\text { Research }\end{array}$ & Label \\
\hline Mark Smith & $\begin{array}{l}\text { Superficial } \\
\text { understanding of } \\
\text { classroom research } \\
\text { including the process, } \\
\text { the benefits and its } \\
\text { significance. }\end{array}$ & $\begin{array}{l}\text { Unwilling to engage } \\
\text { in any classroom } \\
\text { research, perceiving } \\
\text { it as not part of a } \\
\text { teachers' job } \\
\text { description. }\end{array}$ & $\begin{array}{l}\text { Identified several } \\
\text { barriers indicating } \\
\text { that these were } \\
\text { insurmountable. }\end{array}$ & $\begin{array}{l}\text { Content-centred } \\
\text { teacher }\end{array}$ \\
\hline Sheri Norma & $\begin{array}{l}\text { Thorough } \\
\text { understanding of } \\
\text { process of classroom } \\
\text { research and an } \\
\text { advocate for the } \\
\text { benefits of this activity } \\
\text { to students. }\end{array}$ & $\begin{array}{l}\text { A practising } \\
\text { classroom researcher } \\
\text { since graduating from } \\
\text { the PDEP. }\end{array}$ & $\begin{array}{l}\text { Identified barriers } \\
\text { but explained that } \\
\text { teachers have to } \\
\text { find ways to } \\
\text { overcome them in } \\
\text { order to meet the } \\
\text { needs of the } \\
\text { students. }\end{array}$ & $\begin{array}{l}\text { Student-centred } \\
\text { teacher }\end{array}$ \\
\hline Pauline Peters & $\begin{array}{l}\text { Fair understanding of } \\
\text { the processes involved } \\
\text { in classroom research } \\
\text { but agreed that it is an } \\
\text { activity worth pursuing } \\
\text { to make the classroom } \\
\text { learning more } \\
\text { meaningful to students. }\end{array}$ & $\begin{array}{l}\text { Unwilling to engage } \\
\text { in research for fear of } \\
\text { being incompetent in } \\
\text { the theory of the } \\
\text { process indicating } \\
\text { that once competence } \\
\text { is acquired the } \\
\text { willingness to } \\
\text { conduct classroom } \\
\text { research will be } \\
\text { there. }\end{array}$ & $\begin{array}{l}\text { Identified barriers } \\
\text { and saw the } \\
\text { difficultly in } \\
\text { overcoming them } \\
\text { in the given } \\
\text { context, but agrees } \\
\text { that teachers must } \\
\text { find a way to } \\
\text { overcome them to } \\
\text { make students' } \\
\text { learning } \\
\text { meaningful to } \\
\text { them. }\end{array}$ & $\begin{array}{l}\text { Learning-centred } \\
\text { teacher }\end{array}$ \\
\hline Deo Tobin & $\begin{array}{l}\text { Clueless about the } \\
\text { process of classroom } \\
\text { research. }\end{array}$ & $\begin{array}{l}\text { Unwilling to engage } \\
\text { in classroom } \\
\text { research. }\end{array}$ & $\begin{array}{l}\text { Identified several } \\
\text { barriers that could } \\
\text { hamper anyone } \\
\text { from doing } \\
\text { classroom research }\end{array}$ & $\begin{array}{l}\text { Self-centred } \\
\text { teacher }\end{array}$ \\
\hline $\begin{array}{l}\text { Andrew De } \\
\text { Pezia }\end{array}$ & $\begin{array}{l}\text { Fair understanding of } \\
\text { what is entailed in } \\
\text { classroom research [as } \\
\text { recalled for the PDEP } \\
\text { experience] }\end{array}$ & $\begin{array}{l}\text { Unwilling to engage } \\
\text { in classroom } \\
\text { perceiving it is as } \\
\text { useless in the present } \\
\text { context, but recalled } \\
\text { the benefits the } \\
\text { process could have } \\
\text { for students. }\end{array}$ & $\begin{array}{l}\text { Identified existing } \\
\text { barriers that would } \\
\text { challenge } \\
\text { classroom research } \\
\text { efforts, but } \\
\text { indicated that they } \\
\text { can be overcome } \\
\text { with teacher } \\
\text { commitment. }\end{array}$ & $\begin{array}{l}\text { School-centred } \\
\text { teacher }\end{array}$ \\
\hline
\end{tabular}

